\title{
小規模地域分散型高齢者居住施設の共用空間における 行動特性の男女差に関する考察 SEXUAL DIFFERENCE OF BEHAVIORAL CHARACTERISTIC IN COMMON SPACE IN GROUP HOUSE FOR THE AGED
}

\author{
上和田 茂*, 侯 宇 峰**, 江上 徹*** \\ Shigeru KAMIWADA, Yufeng HOU and Toru EGAMI
}

\begin{abstract}
This study aims at clarifying sexual difference of behavioral characteristic in common space in group house for the aged. The findings are as follows. Female residents often use common space, however male residents moderately do it Female and male residents act on the difference zone in common space. Female residents tend to act collectively, however male residents act individually. Female residents tend to act widely in common space, however male residents act limitedly. Male residents tend to interest in group work by female residents, however they seldom participate in that group. Female residents can adapt easily to community life, however male residents can not do it.
\end{abstract}

\author{
Keywords : small residential facility for the aged, group house, common space, \\ behavioral characteristic, sexual difference, gender \\ 小規模高齢者居住施設，グループハウス，共用空間， 行動特性，男女差，ジェンダー
}

\section{1.はじめに}

\section{(1) 研究の背景と目的}

一般にグループハウスあるいはグループリビングなどと呼称され

る「小規模地域分散型高齢者居住施設」は、「施設ケア」と「在宅年

ア」の両者の特長を兼补備え、自立した生活を送ることが出来る今 後の有力な高齢者居住施設の一つとして大きな関心が寄せられてい

る。また、その設置数も近年増加の傾向にある。

筆者は、別稿 ${ }^{1)}$ において、その全国的な設置状況および入居者の 生活概況について報告を行ったが、施設責任者からの回答に基づき、 男女間における生活上のトラブルが少なくないこと、また入居者間 の接触・交流および相互支援において著しい男女差がみられること など、男女の混住に起因する諸問題の存在を明らかにした。

これまでの高齢者居住施設への入居者の大半は女性が占めていた ことから、男女差が問題視されることはまれであった。しかし、男 性の平均寿命も伸長寸るのに伴い、男性入居者の比率も徐々に高ま ることが推察される 注1)。他方、施設のユニット化や小規模化の進展 に伴い、否応なしに入居者間の接触の度合いが進み、男女差や男女 間のトラブルも増大寸る恐れもある。特に、家事的能力や地域生活 の経験に乏しい男性高齢者においては、共同生活不順応傾向や孤立
化現象などが発生することも予想され注2)、施設内におけるジェンダ 一の問題は看過できない重要な検討事項になるものと推察される。 本研究は、このような状沉を背景として、「小規模地域分散型高齢 者居住施設」での入居者の行動特性における男女差を把握すると共 に、それを通して共同生活に対寸る姿勢や指向における男女差を明 らかにし、今後の空間計画への示唆を得ることを目的とする。

\section{(2) 分析課題と方法}

施設内における入居者の行動場面のうち、入居者どうしの接触・ 交流が頻繁に行われ、また共同生活上の差異や軋堹が生じやすいの は、居間および食堂など共用空間での生活行動であると考えられる。 行動特性上の男女差も、この共用空間における他人との関係、寸な わち他者との距離の取り方において立ち現れると解釈し、それを把 握するために、以下の各事項についてその様相を明らかにする。

(1) 共用空間への来室頻度および滞室時間

(2) 生活行為の内容

(3) 他人との接触・交流の様相

(4) 入居者間およびヘルパーとの会話の状沉

(5) 共同的な家事一の協力状況

(6) 空間的行動パターン特性
* 九州産業大学工学部建築学科 教授·工博

** 九州産業大学大学院工学研究科 博士後期課程 $\cdot$ 工修

*** 九州産業大学工学部建築学科 教授・博士(工学)
Prof., Dept. of Architecture, Faculty of Engineering, Kyushu Sangyo Univ., Dr. Eng. Graduate Student, Graduate School of Engineering, Kyushu Sangyo Univ., M. Eng. Prof., Dept. of Architecture, Faculty of Engineering, Kyushu Sangyo Univ., Dr. Eng. 


\section{（3）小規模地域分散型高齢者居住施設の定義}

本論文が対象とする「小規模地域分散型高齢者居住施設」の定義 は必ずしも確立してはいない。

三浦氏 ${ }^{3) 4)}$ によると、グループハウスは、「グループホームのように 家庭的䨌囲気を重視した小規模な高齢者の住まい」であることから 「グループホーム型小規模高齢者施設」と名付け、その要件として、 「小規模」「地域分散」「地域密着」の 3 者を挙げている。

グループリビングについては、厚生労働省の「介護予防・生活支 援実施要綱」に定められている「高齢者共同生活（グループリビン グ）支援事業」において、「加齢による身体機能の低下を補うため、 共同で生活している形態」とされ、「おおむね 60 歳以上の高齢者」、「5 人〜 9 人」、同一家屋内で食事等、お互いに生活を共同化できるもの」 等の要件が示されている。

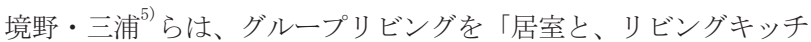
ンなどの共用空間からなる空間構成の中で、比較的小規模（5～10数 名）で行われる共同居住形態」と定義している。

また、近藤・大江 ${ }^{6}{ }^{2}$ は、高齢者グループリビングの定義要件として、 「自立した生活ができる高齢者」、「3名から15名」、「共同居住」「個 室と食事を中心とする共同の場を持つこと」、「介護の専門スタッフ は常駐しないことを原則とする」等を挙げている。

本研究における「小規模地域分散型高齢者居住施設」は、これら の定義や見解を参考にし、しかも、できるだけ広範囲に施設を包含 できることを念頭に、その要件を以下のように定めることにする。 寸なわち、「まちなかに分散的に設置されていること」、「おおむ称 60 歳以上の高齢者」、「20人程度以下」、「共同居住」、「一つまたは一群の 建物中に個室と食事用等の共用空間を有すること」、ただし、高齢者 向け優良賃貸住宅のように、独立住戸が集合化したものは除外する。

\section{(4) 既往研究との関係}

小規模地域分散型高齢者施設を対象とする既往研究には、前記の もののほか、南 $~^{7)}$ 、毛利 ${ }^{8)}$ 、井上 ${ }^{9)}$ 、三浦 ${ }^{10)}$ による事例研究がある が、小規模地域分散型高齢者施設の現状と課題を整理する上で大い に参考になった。また、高齢者居住施設の共用空間を取り扱った研 究には、柿沢 $5^{11)}$ 、井上 $5^{12) 13)}$ 、石井 ${ }^{14)}{ }^{15)}$ 、厳ら ${ }^{16)}$ 、山田 $5^{17)}$ 、鈴 木ら ${ }^{18)}$ 、神吉ら ${ }^{19)}$ 、黒木 $5^{20)}$ など養護老人ホームあるいはグループホ 一ムを対象としたものがあり、研究対象を異にするものの、共用空 間へのアプローチについて多くの手がかりを得た。男女差を主題に

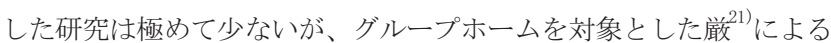
研究は、男女の行動特性の差異を的確に捉えたものであり、多大な 示唆を得た。本研究は、以上の研究を参照しつつ、前述のように、 施設の小規模化による入居者間の接触度の増大に伴う男女間の問題 の進行を想定し、小規模地域分散型高齢者居住施設における行動特 性の男女差に着目して考察することに独自性があると考える。

\section{2. 調査概要}

\section{(1) 調査対象施設の概要}

調查対象施設として、尼崎市のグループハウス A (以下、A施設 という)、愛知県長久手町の B 長屋（以下、B施設という）、福岡県 久留米市のグループリビング K（以下、K施設という）の3施設を選 定した。図1にそれぞれの施設の平面図を示す。

$\mathrm{A}$ 施設は、阪神淡路大震災後に建設されたケア付き仮設住宅を前

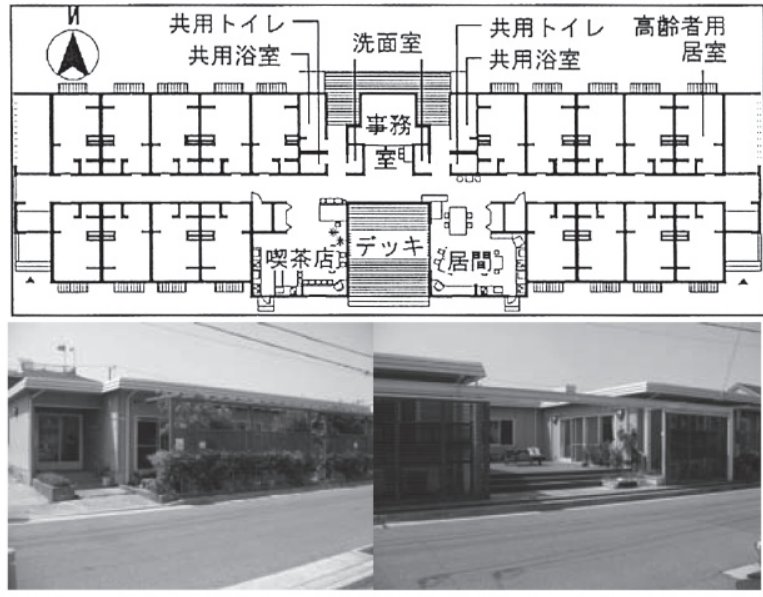

( $\mathrm{A}$ 施設)
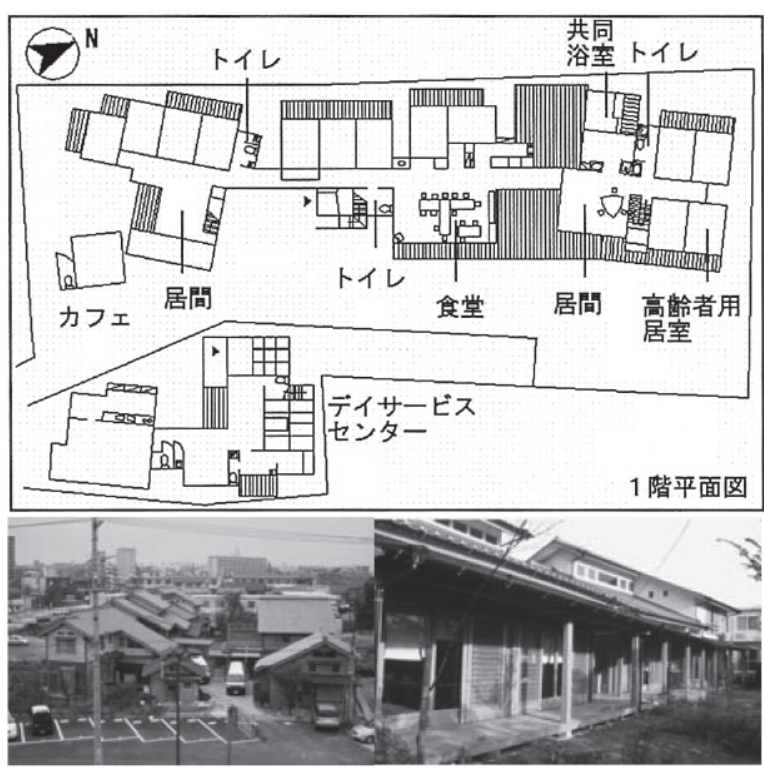

(B施設)

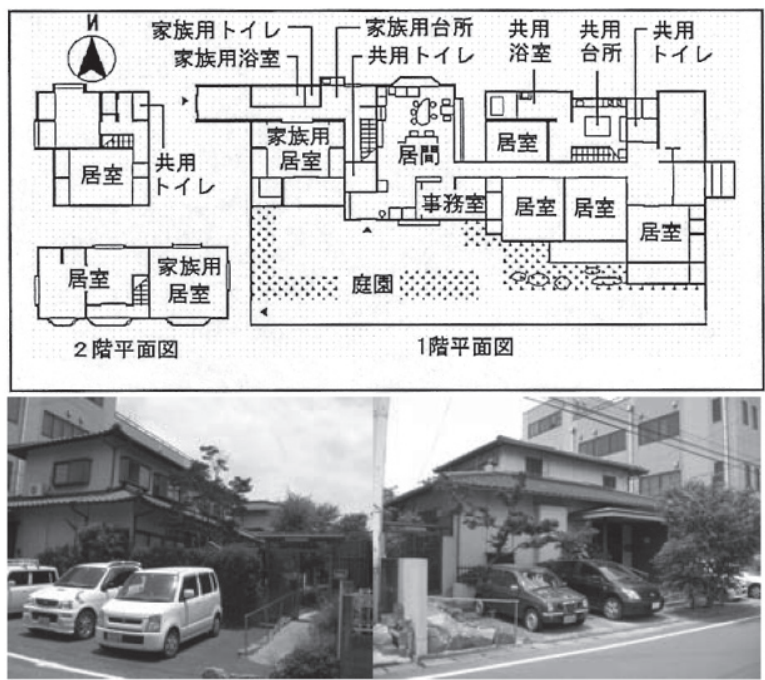

( K施設)

図 1 調查対象施設の平面図・外観写真 
身とし、仮設住宅の撤去後に恒久施設として新設された市立民営の 高齢者居住施設である。LSAが常駐するが、食事づくりをはじめ日常 生活の遂行は入居者自身に委衫られている自立指向型の施設である。 実際には、常駐（介護保険上は訪問看護）および通いのへルパーに より生活支援がなされている。入居可能な居室は16室である。

B施設は、賃貸形式のアパートとして設置されたが、24時間介護お よび完全給食型の運営がなされている社会福祉法人立の施設である。 高齢者のほか、20代〜30代の若い単身女性および家族員 4 名の一般 家族世帯が入居している。高齢者用の居室は 13 室である。

K施設は、民家改修型で、24時間介護付きかつ完全給食型の高齢者 居住施設である。設置および運営主体は有限会社である。入居者の ほか経営者およびその家族計 5 名が居住しているが、入居者 7 名の うち1名は経営者の祖母であり、介護の対象である。入居者の居室は 6 室で、祖母は1階の家族用居室で寝起きしている。

以上の 3 施設は、施設内容、運営方針および入居者属性等において 幾分差異が認められるものの、前述の小規模地域分散型高齢者居住 施設の定義にかない、共通性が高いことから、比較対象する上で特 段の問題はないものと考える。注3）4）

(2) 入居者のプロフィール

$\mathrm{A}$ 施設の入居者数は、女性 11 名、男性 5 名、計 16 名であり、その うち入院中の女性 3 名を除く 13 名を調查対象とした。B施設の高齢 入居者は、女性 7 名、男性 6 名、計 13 名であり、そのうち寝たきり の男性 1 名、入院中の女性 1 名を除く 11 名を調查対象とした。K施 設の高齢入居者は、女性 4 名、男性 3 名、計 7 名であり、その全員 を調査対象とした。各入居者の年龃、要介護度、認知症の有無およ び歩行能力については表 1 に示すとおりである。

\section{(3) 調査方法}

各施設において 1 日 2 ～名の調查員を配置し、各日、各調查員 がそれぞれ 1 名の入居者を担当し、午前 7 時〜午後 7 時の 12 時間の 全生活について追跡観察調查を行い、行為の場所および内容等を記 録した。なお、特定の行事が開催され、通常と大幅に異なる生活が 営まれた調查日のデータは分析から除外した。また、必要に応じて 入居者、経営者およびヘルパーへのインタビューを行った。調查時 期および期間は、A施設は2007年11月の 4 日間、B施設は 2004 年 10 月の 3 日間、K施設は2007年 6 月の 3 日間である。

\section{3．共用空間における行動の様相}

\section{（1）共用空間への来室頻度および滞在時間}

図 2 は、午前 7 時からの 12 時間に各入居者が共用空間に滞在した 時間帯を各施設毎に示したものである。施設差および個人差が認め られるものの、全体として、女性に比較して男性の来室頻度および 滞在時間が低調であることがわかる。この状況をさらに分かり易く するために、来室頻度と滞在時間の 2 軸で男女差を示したものが図 3である。K施設においてやや状況が異なるものの、他の施設では、 女性において来室頻度が多く、滞在時間も長い傾向が、男性では逆 に来室頻度が少なく、滞在時間も短い傾向が読み取れる。

さらに、来室頻度と滞在時間の平均值を表 2 に示す。A施設では、 女性の共用空間（居間・食堂）への来室頻度は平均8.75回、平均滞 在時間3.5時間、男性の来室頻度は平均 5.4 回、平均滞在時間は 1.24 時間であり、女性に比較して男性の来室頻度は少なく、滞在時間も
表 1 入居者のプロフィール
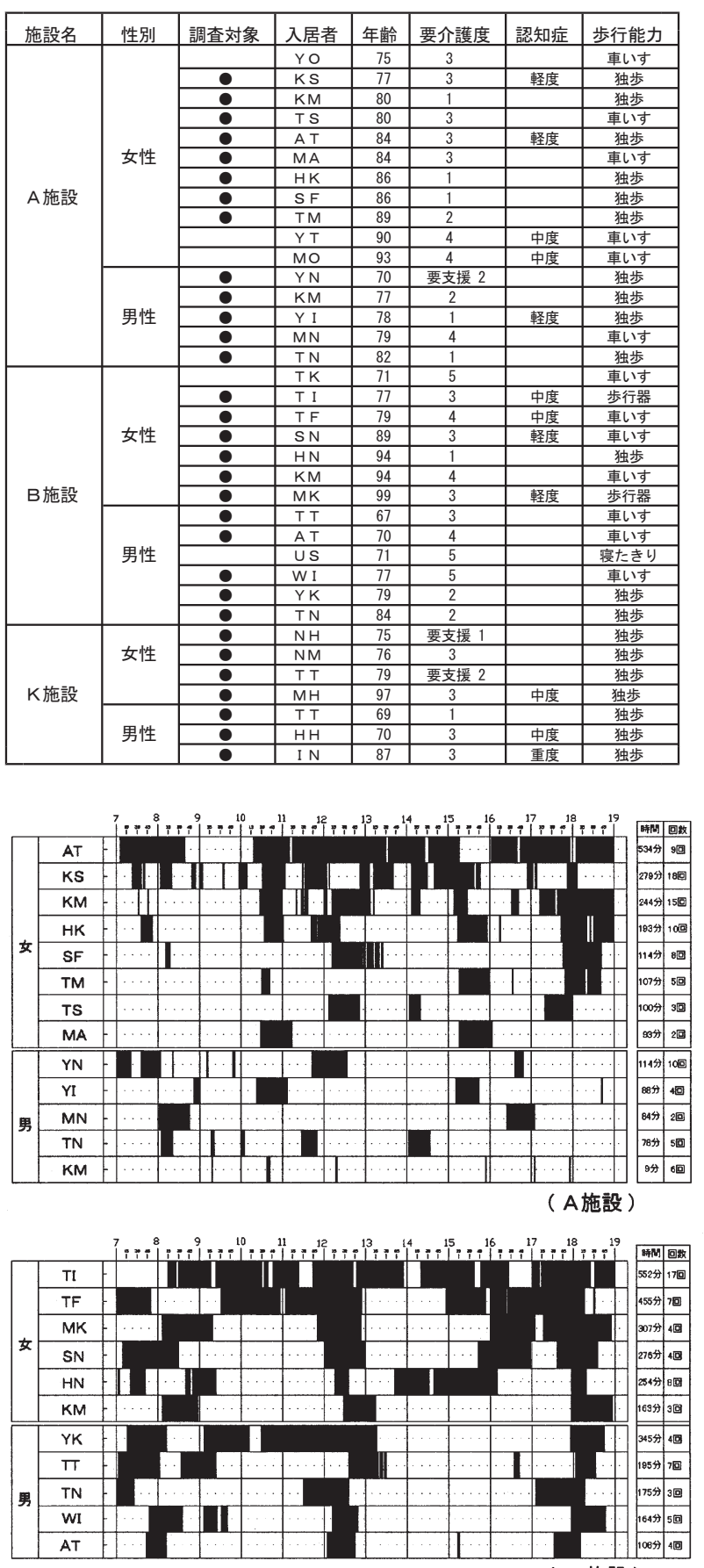

( B 施設 )

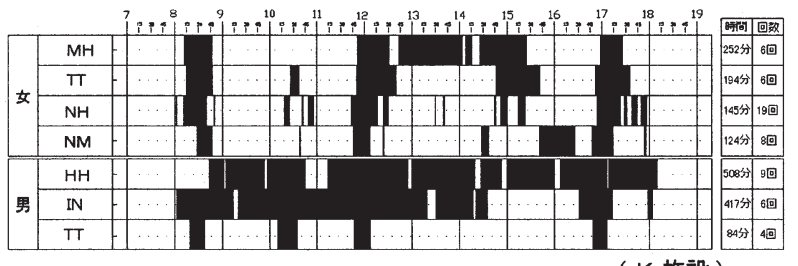

( $\mathrm{K}$ 施設 )

図 2 共用空間への来訪頻度および滞在時間

短い。特に平均滞在時間が他の 2 施設に比較して極端に短い。

B 施設でも、女性の来室頻度は平均7.16回、滞在時間は平均 5.60 時間、男性の来室頻度は平均4.60回、滞在時間は平均 3.29 時間であ 


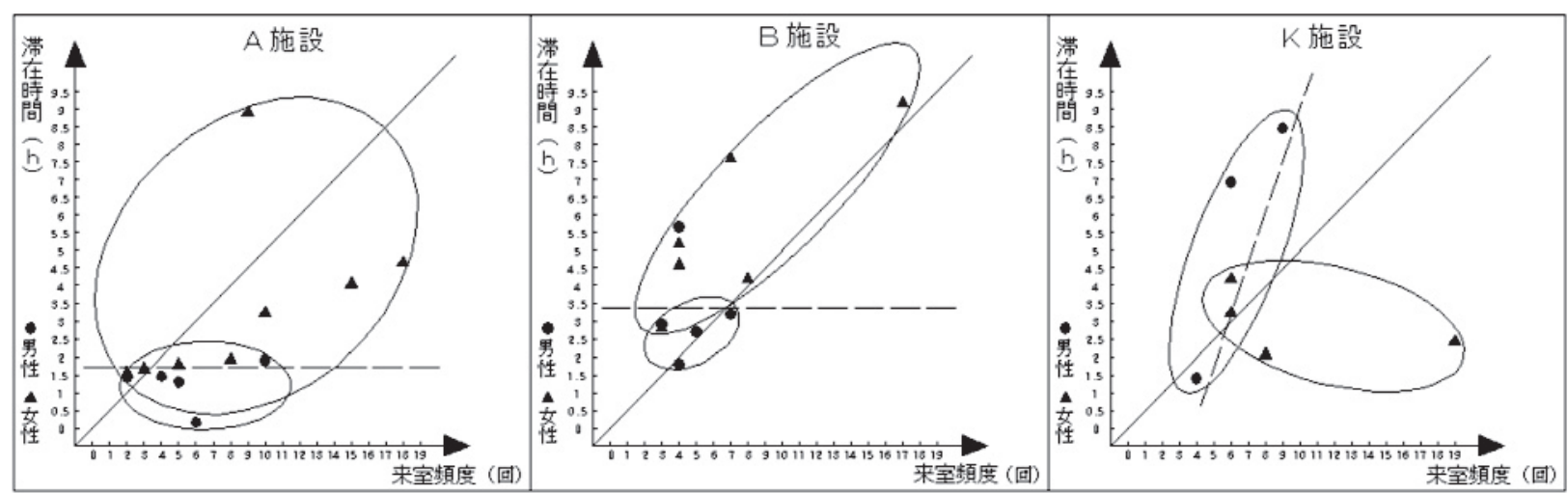

図 3 共用空間への来室頻度と滞在時間の相関

り、女性に比較して男性の来室頻度は少なく、滞在時間も短い。

施設 $\mathrm{K}$ では、女性の来室頻度は平均9.75回、滞在時間は平均 3.00 時間、男性の来室頻度は平均6.33回、滞在時間は平均5.60時間とな っており、滞在時間において女性より男性の方が長くなっている。 これは他の 2 施設にはみられない傾向であるが、その原因は、認知 症の男性 2 人に対してへルパーの介護が行き届くように、できるだ け共用空間への滞在を誘導し、それが習慣化したことにある。

ここで、入居者が有する行動能力に関する属性等の影響について ふれておく。表 1 に示した「要介護度」、「歩行能力」、「認知症の有無 および程度」の 3 要因と「共用空間での滞在時間」との相関を略確認 したところ、要介護度との相関はわずかにみられる程度、歩行能力 との相関もわずかにみられる程度に過ぎないが、認知症との相関に ついてはかなり認められるとの結果を得た（表 3 ）。上記のK施設に おける認知症の男性 2 名の滞在時間が女性のそれを上回ったのは、認 知症の影響が行動特性における男女差の影響を凌駕したことによる ものである。

\section{（2）共用空間における生活行為の内容}

A 施設の場合、女性では、1名を除く他の 8 名は朝・昼・夕の 3 度の食事のため共用空間を利用寸る。また、女性の半数は、食事以 外にテレビ視聴、食後や催し事の後の談話、ヘルパーの手伝いなど、 多様な行為を行っている（写真 1 )。また、共通のプログラムである 午前10時30分からのテレビ体操、その直後および15時のおやつには 8 名中6名が参加するなど集団的な活動への参加度も高い（写真 2 ）。一 方、男性では、共用空間で食事を行うものは 5 名中 1 名である。また、 テレビ体操やおやつに参加する者も 1 名に過ぎず、集団的な活動 の参加度も低い。来室の際には、新聞を読む、台所での調理、なに げなく周囲を見渡すなど、個人的な活動に終始している。

B 施設の場合、女性では、食事以外に、テレビ視聴、趣味的活動、 生け花、喫茶など多様な行為を行っている。集団的な活動も 2 グルー プに分かれて頻繁に行われている。しかし、男性では、6名中5名は 食事以外に共用空間を使用寸ることは皆無に近い。残り 1 名の男性は 夫婦で入居しており、夫人と他の女性入居者との縁もあって、女性 入居者に混じって行動することが多くみられる（写真 3 )。

K施設の場合、女性は、食事、テレビ視聴のほか書道、卓球など のレクリエーション、おやつの後の談話、ヘルパーの手伝い、施設 で飼っている犬、鳥、亀などの世話など多様な行為を行っている。 また、15時のティータイムなど集団的な活動にも全員が参加する。 一方、男性では、食事以外には、新聞を読む、テレビを時々視聴、
表 2 共用空間への平均来室頻度および平均滞在時間

\begin{tabular}{|c|c|c|c|c|c|c|}
\hline \multirow[b]{2}{*}{ 性別 } & \multicolumn{3}{|c|}{ 平均来室頻度 (回 $/$ 人 . 日) } & \multicolumn{3}{|c|}{ 平均滞在時間 $(h /$ 人 - 日 ) } \\
\hline & A 施設 & B施設 & K施設 & A施設 & B施設 & K施設 \\
\hline 女性 & 8.75 回 & 7.16 回 & 9.75 回 & $3.50 \mathrm{~h}$ & $5.60 \mathrm{~h}$ & $3.00 \mathrm{~h}$ \\
\hline 男性 & 5.40 & 4.60 & 6.33 & 1.24 & 3. 29 & 5.60 \\
\hline
\end{tabular}

表 3 要介護、歩行能力、認知症の有無と滞在時間の相関

\begin{tabular}{|c|c|c|c|c|c|c|c|c|}
\hline \multirow{2}{*}{ 滞在時間 } & \multicolumn{4}{|c|}{ 要介護度 } & \multicolumn{3}{|c|}{ 歩行能力 } & \multicolumn{2}{|c|}{ 認知症の有無 } \\
\hline 0時間 & $7(50)$ & $2(17)$ & $2(40)$ & $7(35)$ & $0(-)$ & $4(44)$ & $1(10)$ & $10(48)$ \\
\hline 2時間 & $4(29)$ & $2(17)$ & $2(40)$ & $5(25)$ & $0(-)$ & $3(33)$ & $0(-)$ & $8(38)$ \\
\hline 4時間 & $3(21)$ & $8(67)$ & $1(20)$ & $8(40)$ & $2(100)$ & $2(22)$ & $9(90)$ & $3(14)$ \\
\hline 合計 & $14(100)$ & $12(100)$ & $5(100)$ & $20(100)$ & $2(100)$ & $9(100)$ & $10(100)$ & $21(100)$ \\
\hline
\end{tabular}

あるいはリハビリを兼ねた習字や漢字の読み取りなどを行っている が、全て個人的な活動に終始している。15時のティータイムの際に も集団の中に入らず、傍観者的に振る舞う（写真 4)。

以上のように、女性に比較して共用空間における男性の行動や活 動が控え目であること、女性は集団的活動を好む傾向があるのに対 して、男性は個人的な行動に終始する傾向があることが判明した。

（3）他人との接触・交流の様相

A施設の場合、女性では、食事の際などに同じテーブルに着いた ものどうしの会話や食後における談話、あるいは情報交換など多彩 な交流が展開されている。また、常日頃から友人関係にあるものも 3 組あり、女性入居者間の接触・交流は盛んである。男性の場合は、

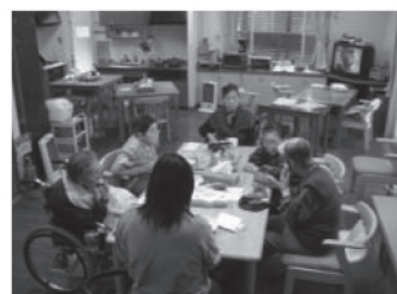

写真 1 食事後の談話 (A施託)

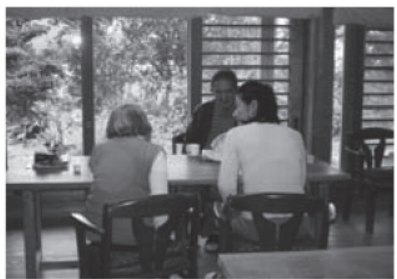

写真 3 ティータイム (B施設 $)$

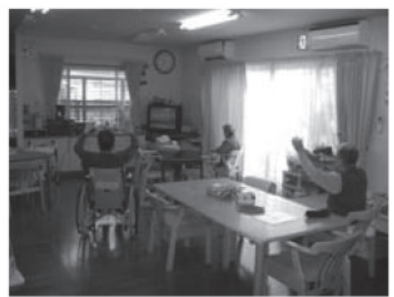

写真 2 テレビ体操 (A施設)

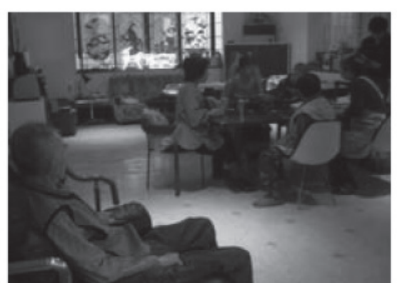

写真 4 ティータイム（K施設） 
恒常的な友人関係を結んでいるものは皆無であり、また偶発的な接 触・交流もほとんどみられない。ただし、女性入居者との挨拶程度 の偶発的な接触は極くわずかではあるが認められる（写真 5 )。

$\mathrm{B}$ 施設および $\mathrm{K}$ 施設の場合もほぼ $\mathrm{A}$ 施設と同様の傾向にある。特 に、B施設では、夫婦で入居している男性を除くと、他 5 名は男性ど うしの接触はもとより女性との接触も全くみられない。むしろ頻繁 に来訪する家族との接触が多いのが特徴的である。したがって、他 入居者との接触・交流が少ない理由として性的特有性以外の要因の 存在を認めざるを得ない。ただし、このような家族依存の生活パタ 一ンも男性高齢者の特有性の一つであると解釈できなくはない。

\section{（4）入居者間およびヘルパーとの会話の状況}

上記の接触・交流の様相を会話の状況から確認寸ると表 4 に示す とおりである。会話の計測にあたっては、相手との一続きの会話で はなく、1つの発話を 1 回とカウントした。

A施設の場合、女性では、1人 1 日平均 34 回の会話がなされてい る。ただし、その相手の 7 割はへルパーであり、他の入居者との会 話は9.6回で、全体の 3 割にとどまる。それでも男性に比較すると随 分多い。男性では、1 日平均24回で、会話総数は女性に比較して極 端に少ないというわけではない。しかし、その9割弱はへルパーとの 会話であり、他の入居者との会話はわずか 1 割である。また、入居 者間の会話相手の性別をみると、女性では全体の 8 割強が同性であり、 異性である男性との会話は 2 割弱と少ない。男性では、会話総数が 2.8回と極少であるので分析に耐えない面があるが、その9割は異性 である女性との会話であり、男性同士の会話は皆無に等しい。

K施設の場合もほぼ同様の傾向を示寸が、男女間の会話が $\mathrm{A}$ 施設 に比較して多いのが特徽的である。入居者総数が 7 名と少人数で家庭 的䨌囲気が強く、また女性 4 名中 2 名が社交的で男性にも声をかける ことが多いことによる。なお、B施設については、調査当時、会話 状況の分析を企図しておらず、実情を把握していない。

以上、会話の状況からみても、女性に比較して男性では他入との 接触・交流において控え目で、孤立化している印象がうかがえる。

\section{（5）共同的家事への協力状況}

A施設の場合、女性は、散らかった物の後片づけやリサイクル用 の折り込みチラシの整理（写真6 )、イベントの準備作業など、共同 的な家事作業に協力寸るケースが頻繁にみられるのに対して、男性 ではほとんどみられない。B施設でも、女性は食器洗いやナプキン の折りたたみ作業（写真 7 ）、あるいは共用空間に摘み花を飾るなど 思い思いの役割を果たしているが、男性の場合は極めて少ない。 $\mathrm{K}$ 施設でも、女性は食事後の食器の後片づけや飼育している犬、鳥、 亀などの世話をよく行っているが、男性では皆無である。

\section{4. 空間的行動パターン特性}

\section{（1）男女の行動領域の形成}

共用空間内での食事時および休㮩時等における入居者の着座の全 体的状況に基づき、男女別の領域形成の実態を把握した。

B施設では、食事の際、図 4 に示寸ように、男性 1 名の座席が例 外的ではあるものの、女性が座を占める領域と男性が座を占める領 域のそれぞれが極めて明確に形成されている。施設側が誘導したわ けではなく、自然に形成されたものである。

K施設の食事の際（図 5 ）も、ほぼ同様に女性の領域と男性の領

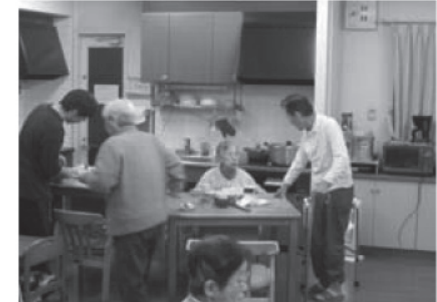

写真 5 男女の偶発的な接触（A施設）

表 4 会話の状況

(A施設)

\begin{tabular}{|c|c|c|c|c|c|c|}
\hline \multirow[b]{2}{*}{ 性別 } & \multicolumn{3}{|c|}{ 発話総数（回 /人·日） } & \multicolumn{3}{|c|}{ 性別入居者間発話回数 (回/人·日) } \\
\hline & 入居者間 & ヘルト์ட & 合計 & 同性間 & 異性間 & 合計 \\
\hline \multirow[t]{2}{*}{ 女性 } & 9.6 回 & 24.4 & 34.0 & 8.0 回 & 1.6 & 9.6 \\
\hline & 28. $2 \%$ & 71.8 & 100.0 & $83.3 \%$ & 16.7 & 100.0 \\
\hline \multirow[t]{2}{*}{ 男性 } & 2.8 回 & 21.2 & 24.0 & 0.2 回 & 2.6 & 2. 8 \\
\hline & $11.7 \%$ & 88.3 & 100.0 & 7.1 & 92.9 & 100.0 \\
\hline
\end{tabular}

( K施設)

\begin{tabular}{|c|c|c|c|c|c|c|}
\hline \multirow{3}{*}{ 性別 } & \multicolumn{2}{|c|}{ 発話総数 (回/人·旦) } & \multicolumn{3}{|c|}{ 性別入居者間発話回数 (回/人·日) } \\
\cline { 2 - 7 } 女性 & 18.5 回 & 56.0 & 74.5 & 11.0 回 & 7.5 & 18.5 \\
\cline { 2 - 7 } & $24.8 \%$ & 75.2 & 100.0 & $59.5 \%$ & 40.5 & 100.0 \\
\hline 男性 & 5.6 回 & 39.7 回 & 45.3 回 & 0.3 回 & 5.3 & 5.6 \\
\cline { 2 - 7 } & $12.4 \%$ & 87.6 & 100.0 & $5.4 \%$ & 94.6 & 100.0 \\
\hline
\end{tabular}

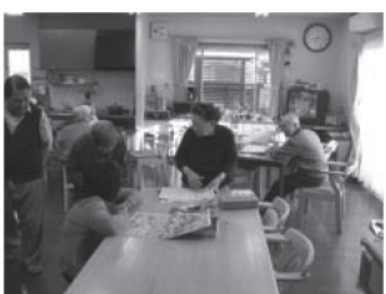

写真6 チラシの整理 (A施設)

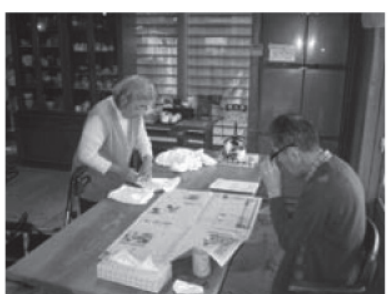

写真7 ナプキンの折りたたみ (B施設
域が分かれている。また、食事以外の休息時あるいは趣味的活動に おいて (図 6 )、女性の行動領域が共用空間のほぼ全域にわたるのに 対して、男性の行動領域は共用空間内の南側のエリアに偏在してお り、緩やかながら男女独自の行動領域が形成されている。また、女 性においては北側のエリアを中心に行動するものと南側のエリアを 中心に行動するものに分かれる傾向が認められる。これも特に誘導 されたわけではなく、自然発生的に生じた現象である。(写真 8，9）

A施設では、食事で共用空間を利用する男性は1名しかいないこと から領域形成は定かではないが、その他の談話、休息、新聞読みな どで共用空間が利用される際、女性が座る場所と男性が座る場所は、 緩やかながら、それぞれの領域構成が認められる。

以上のように、共用空間において、施設により、また活動場面に

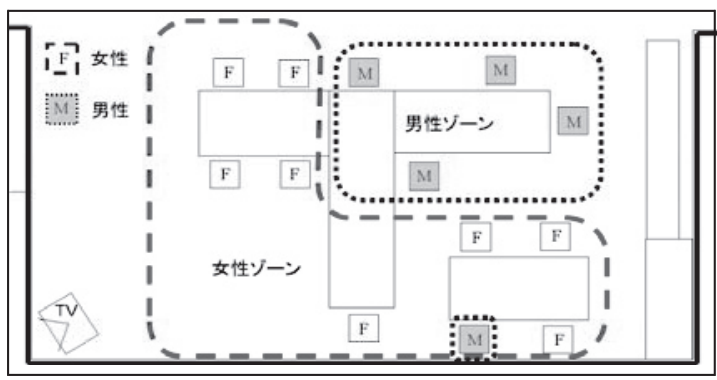

図4 食事時における男女の領域区分（B施設の場合） 


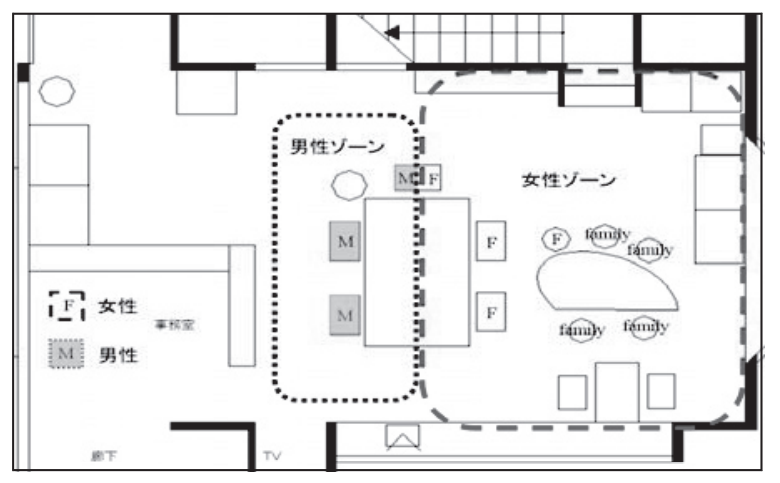

図 5 食事時における男女の領域区分（K施設の場合）

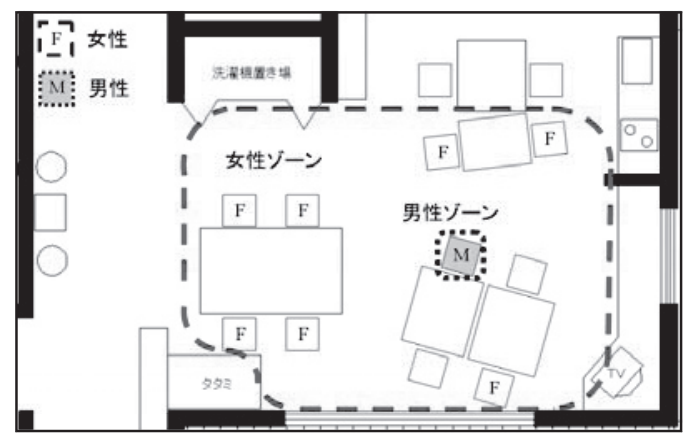

図7 食事時における男女の領域区分（A施設の場合）

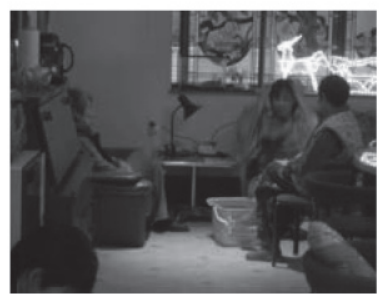

写真8 女性の領域（K施設）

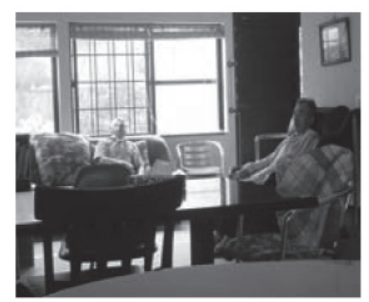

写真9 男性の領域（K施設）
より強弱はあるものの、女性の行動領域と男性の行動領域が形成さ れていることが認められる。また、領域の形成のされ方には、男女 の領域が明確に区分される場合と、男性の領域が女性の領域に重な りかつ包含されるような場合の2種類があることが観察された。

(2) 面的行動と点的行動

図 9 に示寸ように、女性の場合は、共用空間に居る時は概ねイス ソファ等の定位置に座り、そこを拠点とするある一定の領域におい て、ある程度長い時間をかけて行動する傾向がみられる。一方、男 性の場合、全般的にみて腰を落ち着かせて共用空間を利用すること は少ない。共用空間に姿を現す時でも、A施設（前出図 7 参照）や B 施設（前出図 4 参照）のように定位置で食事をした後はそのまま 居室に直帰したり、他の行為で共用空間を利用寸る場合でも、K施 設（図 9）のように一籄所にとどまるか、A施設（図 9）でみられ るように、共用空間内に長時間とどまることなく、室内を必要に応 じてスポット的に動き回る行為が認められる。

このような行動の差異を、ここでは面的行動と点的行動と称し、 それぞれ次のような定義を与える。すなわち、面的行動は「座位に よる利用が数箇所にわたり、連動的かつ多数回利用すること」、点的

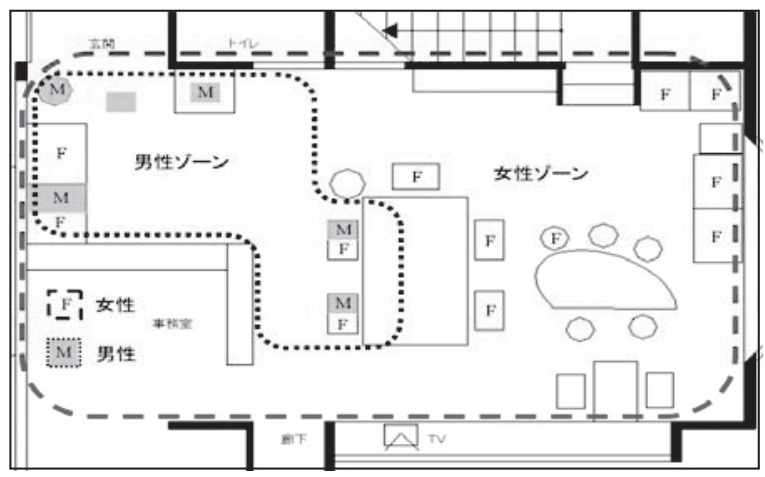

図 6 休憩時等における男女の領域区分（K施設の場合）

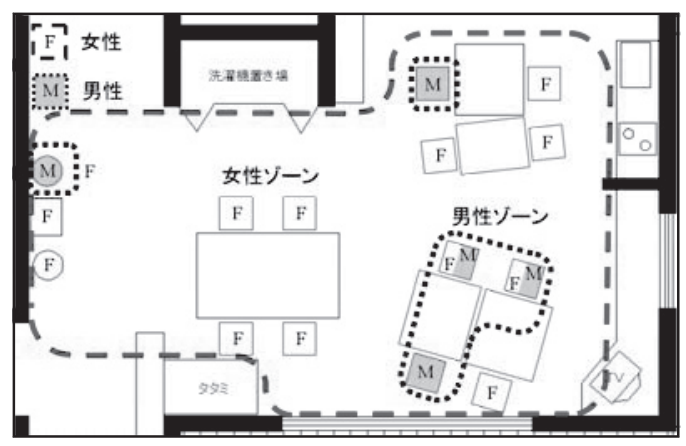

図8 休款時等における男女の領域区分（A施設の場合）
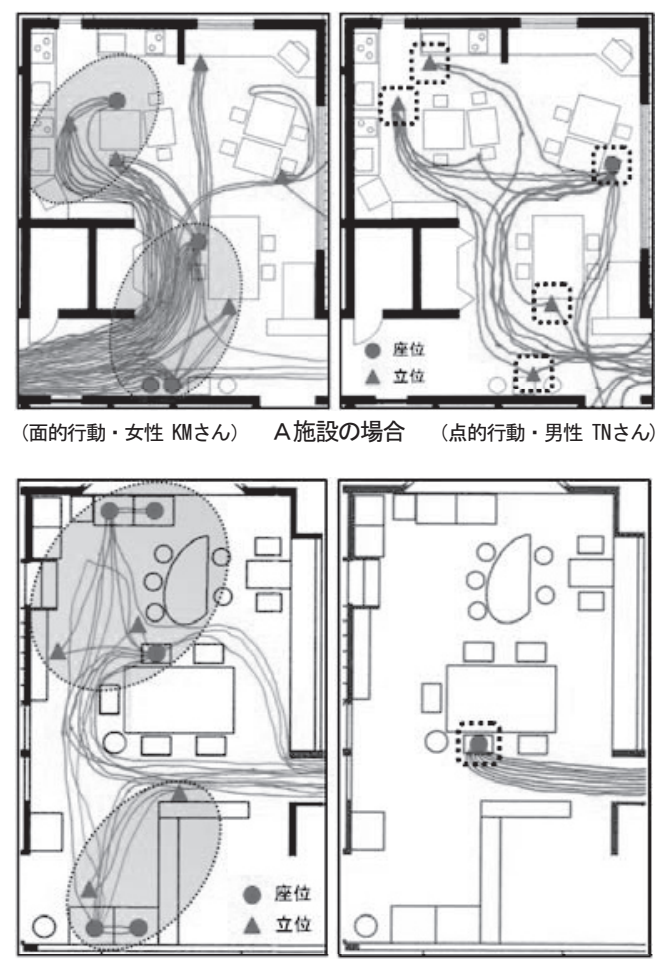

（面的行動·女性 TTさん） K施設の場合（点的行動·男性 TTさん） 図9 女性の面的行動パターンと男性の点的行動パターン

行動は「1箇所または極く少数の箇所を利用する」か、「多数箇所を 巡回寸る場合でも 1 箇所当りの滞在回数は少なく、かつ立位により極 く短時間ずつ利用すること」とする。図10は、座位による滞在箇所 
数および滞在回数を男女別に示したものである。これによると、滞 在籄所数については、3箇所以上のものが男性15\%（2/13名）に対し て女性 $56 \%$ （10/18名）、滞在回数については、6回以上のものが男 性15\%（2/13名）に対して女性61\%（11/18名）と、いずれも女性が 大幅に上回っており、上記の事実の一端が裏付けられた。

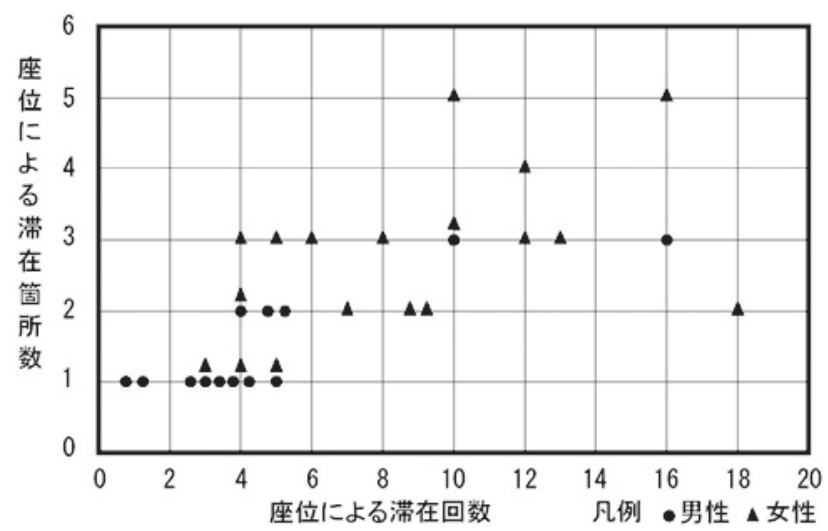

図10 座位による滞在箇所数および滞在回数

\section{（3）集団への間接的接触指向}

上記の点的行動と関連して、男性に特徴的な行動特性の一つとし て、集団への間接的な接触指向と言えるような現象を指摘できる。 この場合、接触の対象はほとんど女性の集団である。図11は、A施 設におけるある男性入居者のそのような行動を例示したものである。 食事中の女性集団の周囲を散歩するように回遊し、時々立ち止まり、 食事に目をやったり、会話に耳をそばだてる行動がみられる。また、 自らは参加しないものの、近くのイスに座って、女性群が $\mathrm{T} V$ 体操 を行っている様子を観察している。このように、決して直接にはそ の集団に関わろうとはしないものの、関心を強く示し、あたかも集 団に間接的に参加しているような、あるいは参加を望むかのような 行動を取っている。この男性の場合、1 日に 7 回行われていた。他 の男性 2 名においても、それぞれ 1 日 2 回および 3 回観察された。

K施設でも、ティータイムなど女性が集団になって食卓で談笑し ている際に、ある男性入居者が近くに置かれているソファに座って、 女性集団の方向に頻繁に視線を注ぎ関心を示す気配が 1 日 4 回観察 された。こういった現象は女性においても散見されるものの、特に 男性に目立つ行為である。

\section{4.まとめ}

以上、 3 施設における事例調查の考察により、共用空間における 行動特性には質量共に顕著な男女差が存在することを究明した。

その特徴を列記すると次のとおりである。すなわち、(1)女性の行 動における集団化傾向と男性の行動における個人化傾向、(2)女性の 行動領域と男性の行動領域の相対的な分離傾向、(3)女性における面 的行動傾向と男性における点的行動傾向、(4)男性における女性集団 への間接的接触指向の諸点である。

これらは、「他者に対する距離の取り方」において男女差が存在す ること、同時に男性における共同生活不順応傾向または孤立化傾向 を示唆するものでもある。今後の高齢者のケアにあたっては、これ まで以上に精神的・情緒的領域に踏み込み、きめ細かな対応が求め

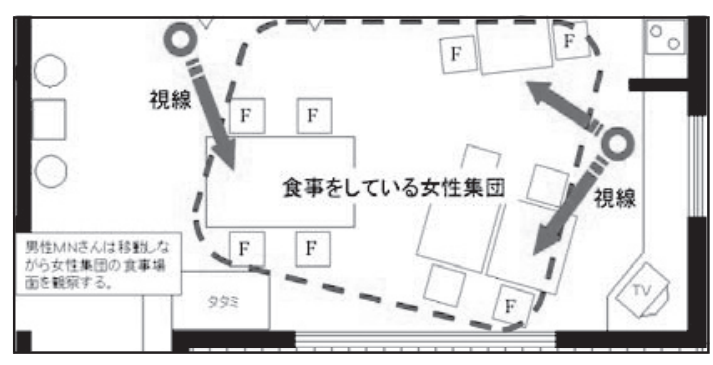

( $\mathrm{A}$ 施設)
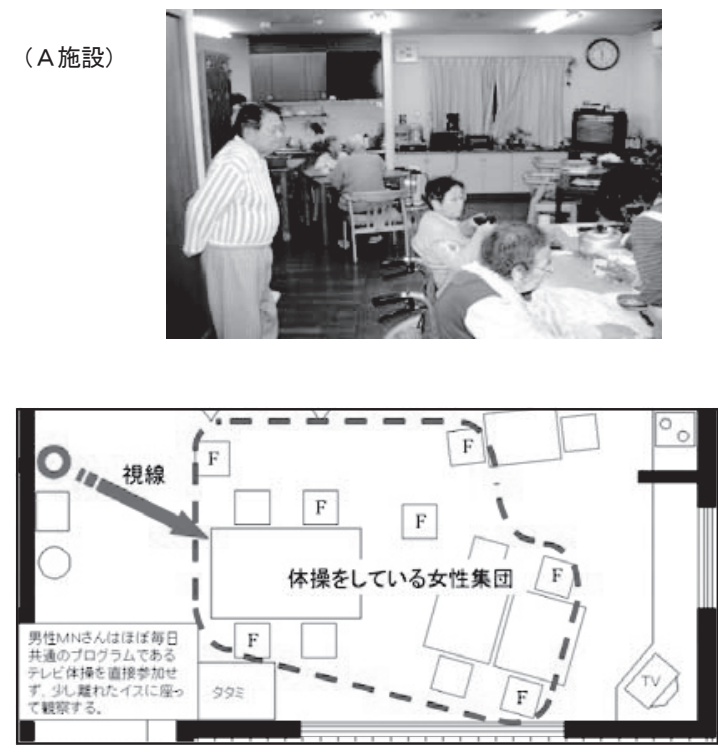

( $\mathrm{A}$ 施設)
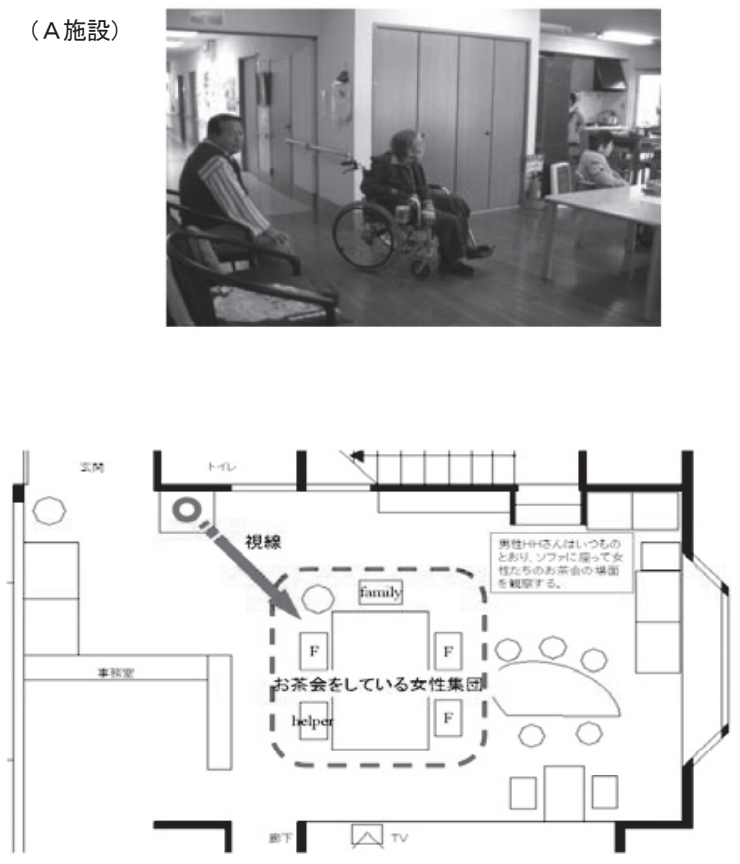

( K施設)

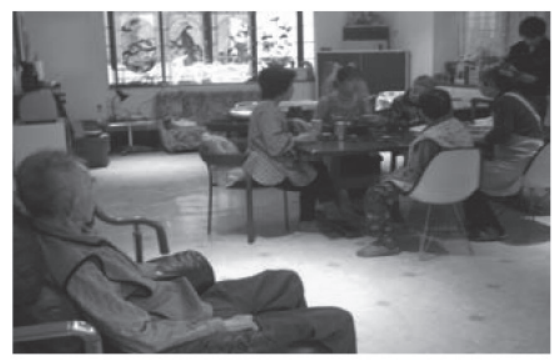

図11 男性における集団への間接的接触指向 
られるものと推察される。今回明らかになった男女差、特に共同生 活に不慣れな人が多い男性への対応が求められる由縁でもある。

もとより、この男女差は過度に強調されるべきではない。性別に 関係なく、個人差として理解されるべき側面もある。また、男女差 は文化的な問題でもある。年代はもとより、本人の生活履歴や退職 前の職業のほか多様な要因によるものであり、時代の変遷と共に今 後大きく変化することも予想される。

また、この結果はわずか 3 施設での調査分析によるものであり、 仮説的な域を出るものではない。今後、さらなる追究が必要である。

なお、限られた考察の範囲ではあるが、共用空間計画への具体的 な示唆として、次の点を指摘しておきたい。それは、集団的活動の 拠り所となる食卓やリビングセットなどの中心的な座具にとどまら ず、その周辺に、付属的な座具コーナーを点在させることが有効で はないかと推察される点である。そのような配慮により、傍観や傍 聴を通して個人の集団に対する間接的な接触や参加を促進寸ること が可能になる。K施設において、そのようなしつらえがなされてい ることが示唆的である。もとより、それを可能にするには室面積の 確保が不可欠である。表 5 に示されているように、K施設の 1 人当 たりの共用空間の面積は広く、そのことを裏付けている。

表 5 共用空間の面積

\begin{tabular}{|l|c|c|c|}
\hline 施設名 & 入居者数 & 共用空間の面積 & 1人当たり面積 \\
\hline $\mathrm{A}$ 施設 & 16 名 & $33.20 \mathrm{~m}^{2}$ & $2.08 \mathrm{~m}^{2}$ \\
\hline $\mathrm{B}$ 施設 & 13 名 & $34.04 \mathrm{~m}^{2}$ & $2.62 \mathrm{~m}^{2}$ \\
\hline $\mathrm{K}$ 施設 & 7 名 & $32.60 \mathrm{~m}^{2}$ & $4.66 \mathrm{~m}^{2}$ \\
\hline
\end{tabular}

\section{謝辞}

調査にあたっては、特別養護老人ホーム「園田苑」施設長・中村 大蔵氏、NP0法人「杂倠木林物語」・遠藤学氏および横山氏、有限会社 ピアネット社長・平山綾子氏をはじめ各施設の職員の方々、日本福 祉大学・毛利志保氏、九州産業大学大学院修了生・高涵氏に多大な ご協力をいただいた。ここに記して深甚の謝意を表する。

なお、本研究は、平成18年度・19年度科学研究費 (基盤研究 C ・ 一般、課題番号18560620）の助成を受けて実施したものである。

注

注1）高齢社会白書によると、平成 16 年 20 年の 5 年間における高齢者人口の性 比（女性人口 100 人に対する男性人口の割合）は、前期高齢者で $587.2 \%$ 、 $87.4 \% 、 87.6 \% 、 88.4 \% 、 88.7 \%$ 、後期高齡者で $57.5 \% 、 58.1 \% 、 58.9 \% 、 59.4$ $\% 、 60.0 \% 」$ と推移し、男性高齢者の比率は増加傾向にある。この数值は 必ずしも施設への入居者数の増加傾向を示寸ものではないが、その傾向を 間接的に裏付けるデータであると考えられる。

注2）引用文献 22)によると、「男性たちの生活の仕方をじっくり見ていると、 さまざまな場面で、女性のサポートを前提にしていることに驚かされる。 （中略）女性にサポートしてもらうのはあたりまえと勝手に思っているか ら、このサポートがなくなると、男性たちは急にオタオタしてしまう」と あり、筆者もこの見解に同意するものである。

注3）A施設は「自立指向型施設」としているが、あくまで設置理念上のことで あり、実際には他の 2 施設における生活の営み、特に行動特性において大 差があるわけではなく、3 施設を類似施設と解釈することに問題はない

注4）B施設には、食堂のほか居間と称される空間が設置されているが、実際 には、その 1 つはへルパーの作業コーナーとして、他の 1 つは応接コーナ 一的な用途になっており入居者の利用はほとんどみられない。一方、食堂 は食事空間としての利用に加え居間的な利用が盛んで、実質的には食堂兼 居間となっており、他の 2 施設の状況とほぼ等しい。

\section{参考文献}

1) 侯宇峰・上和田茂 : 小規模地域分散型高齢者居住施設の設置動向および生 活概況、日本建築学会地域施設計画研究 25、pp.239-244、2007.7

2）侯宇峰 -上和田茂・船越正啓 : 小規模地域分散型高齢者介護居住施設に関
する研究、在宅的要素、ジェンダー、多世代共住の視点からの考察、日本 建築学会地域施設計画研究 24、pp.245-252、2006.7

3）三浦研・中村大藏：ひだまりの中でおしゃべり、会話の分析から見たグル ープハウス・ケアの特徵、のびのびくらすブックレット1、地域型高齢者 協㗢居住推進委員会発行、2000.2

4）三浦研・京都大学旧外山義研究室 : グループハウスという住まい方、震災 が生んだ介護力ある協働居住、建築雑誌、第 118 集 1510 号、pp.32-33、2003.10

5 ）境野健太郎・富田啓介・三浦研・高田光雄 : グループハウス入居高龄者の 生活実態への考察、高齢者グループリビングにおけるケアシステムに関す る研究その 1 、日本建築学会大会学術講演梗概集 (近畿) E-2、pp.147-148、 2005.9

6）近藤恭代・大江守之：高齢者グループリビングに関する基礎的研究、日本 建築学会大会学術講演梗概集（北陸） E-2、pp.345-346、2002.8

7 ）南智英・長澤泰 : 高齢者共同居住における共用空間のあり方に関する研 究、グループリビングのケーススタディ、日本建築学会大会学術講演梗概 集（関東）E-2、pp.355-356、2006.9

8）毛利志保 : 住まい化への整備過程からみた高齱者居住施設のありように関 寸る研究、「第 5 章 小規模多機能・地域分散型居住における利用者の生活 様態、私家版 (学位論文)、pp.157-192、2004.3

9）井上由紀子：いえとまちのなかで老い衰える、第 4 章 3 節ケア付き長屋に おける地域居住のかたち、pp.119-136、中央法規、2006.5

10）三浦研・外山義・阪上由香子・和㴊大・小林正美：ケアおよび会話分析に 基づく入居者一職員の関係性と生活展開、小規模グループリビングに関す る研究 (その1)、日本建築学会計画系論文集、第535号、pp.91-97、2000.9

11）柿沢英之・石井敏・長澤泰・山下哲郎 : 入居者のグループ形成とその特性 に関する考察、一個室型特養老人ホームの「集まり」に関する事例研究一、 日本建築学会計画系論文集、第493号、pp.153-159、1997.3

12）井上由起子 - 外山義 - 小滝一正 - 大原一興 : 高龄者居住施設における入居 者の個人的領域形成に関寸る考察、住まいとしての特別養護老人ホームの あり方に関する研究その1、日本建築学会計画系論文集、第501号、 pp.109-115、1997.11

13）井上由起子 - 外山義 - 小滝一正 $\cdot$ 大原一興・ 橘弘志 - 古賀紀江 : 介護方針 の変更に伴う生活の場の再構築に関する考察、住まいとしての特別養護老 人ホームのあり方に関する研究その3、日本建築学会計画系論文集、第5 24 号、pp.117-123、1999.10

14）石井敏・外山義・長澤泰 : グループホームにおける生活構成と空間利用の 特性、痴呆性老人の環境構築に関する研究、日本建築学会計画系論文集、 第502号、pp.103-110、1997.12

15）石井敏・厳爽・外山義・橘正志・長澤泰 : 先進事例にみる共用空間の構成 と生活の関わり、痴呆性高齢者のためのグループホームに関する研究その 1、日本建築学会計画系論文集、第524号、pp.109-115、1999.10

16）厳爽・石井敏・外山義・橘正志・長澤泰 : グループホームにおける空間利 用の時系列的変化に関寸る考察、「なじみ」からみた痴呆性高齢者のケア 環境に関する研究（その1）、日本建築学会計画系論文集、第5 523 号、 pp.155-161、1999.9

17）山田あすか・上野淳・登張絵夢・竹宮健司 : 痴呆性高齢者グループホーム に打ける居住者による固有の居場所の選択とその要因、日本建築学会計画 系論文集、第556号、pp.145-152、2002.6

18）鈴木健二・外山義・三浦研 : 痴呆性高齢者グループホームにおける空間の 構成と入居者の生活・スタッフのケアの展開、痴呆性高齢者のケア環境の あり方に関する研究 (3)、日本建築学会計画系論文集、第556号、pp.169-176、 2002.6

19）神吉優美・高田光雄・三浦研 : 個室ユニット型養護老人ホームにおけるユ ニット内共用空間の利用実態、一個室・ユニット型養護老人ホームにおけ る入居者の空間利用実態その 1 -、日本建築学会計画系論文集、第592号、 pp.65-70、2005.6

20）黑木宏一・横山俊祐：認知症高齢者のグループホームにおける入居者の過 ごし方からみた「生活の質」の評価、一民家改修型の空間特性による過ご し方の展開一、日本建築学会計画系論文集、第618、pp.19-24、2007.8

21）厳爽 : 男女別でみた認知症高齢者グループホームの生活構成に関する考察 日本建築学会大会学術講演梗概集（関東）E-1、pp.161-162、2006.9

22）伊藤公雄・樹村みのり・國信潤子：女性学・男性学、ジェンダー論入門、 p.17、有斐閣、2005.6 